\title{
Pengembangan Perangkat Pembelajaran Matematika dengan Penemuan Terbimbing pada Materi Bangun Ruang Sisi Lengkung
}

Endang Nurul Hasanah, Abdurrahman, Sri Rezeki, Aulia Sthephani

How to cite : Hasanah, E. N., Abdurrahman, Rezeki, S., \& Sthephani, A. (2021). Pengembangan Perangkat Pembelajaran Matematika dengan Metode Penemuan Terbimbing pada Materi Bangun Ruang Sisi Lengkung. Kognitif: Jurnal Riset HOTS Pendidikan $\quad$ Matematika, 1(2), $164 \quad$ - 177. https://doi.org/10.51574//kognitif.v1i2.110

To link to this article : https://doi.org/10.51574/kognitif.v1i2.110

Opened Access Article

Published Online on 1 Desember 2021

兵 Submit your paper to this journal 


\title{
Pengembangan Perangkat Pembelajaran Matematika dengan Penemuan Terbimbing pada Materi Bangun Ruang Sisi Lengkung
}

\author{
Endang Nurul Hasanah ${ }^{1}$ *, Abdurrahman ${ }^{1}$, Sri Rezeki ${ }^{1}$, Aulia Sthephani ${ }^{1}$ \\ ${ }^{1}$ Program Studi Pendidikan Matematika, Universitas Islam Riau
}

\begin{tabular}{l} 
Article Info \\
\hline Article history: \\
Received Oct 8, 2021 \\
Accepted Oct 12, 2021 \\
Published Online Dec 1, 2021
\end{tabular}

Keywords:

Metode Penemuan Terbimbing

Perangkat Pembelajaran

Matematika

\begin{abstract}
Penelitian ini bertujuan untuk menghasilkan perangkat pembelajaran matematika dengan metode penemuan terbimbing pada materi bangun ruang sisi lengkung yakni berupa Rencana Pelaksanaan pembelajaran (RPP) dan lembar Kerja Peserta Didik (LKPD) yang teruji kevalidannya. Penelitian pengembangan perangkat pembelajaran matematika ini menggunakan model Research and Development (R\&D). Tetapi dikarenakan adanya pandemi COVID-19 hanya 6 tahapan saja yang dilakukan yaitu 1) potensi \& masalah, 2) pengumpulan data, 3) desain produk, 4) validasi desain, 5) revisi desain dan 6) produk akhir. Instrumen pengumpulan data yang digunakan adalah lembar validasi RPP dan lembar validasi LKPD. Teknik pengumpulan data yang digunakan adalah non tes dengan menggunakan angket lembar validasi dari 2 orang dosen pendidikan matematika FKIP UIR dan 1 orang guru matematika SMP Negeri 4 Kunto Darussalam. Teknik analisis data yang digunakan adalah analisis deskriptif kuantitatif yaitu dari analisis data validasi. Dari hasil penelitian diperoleh hasil validasi RPP sebesar 88,53\% dengan kategori sangat valid dan LKPD sebesar 88,71\% dengan kategori sangat valid. Berdasarkan hasil penelitian ini diperoleh perangkat pembelajaran matematika dengan metode Penemun Terbimbing pada materi Bangun Ruang Sisi Lengkung kelas IX SMP yang teruji kevalidannya.
\end{abstract}

This is an open access under the $\underline{C C-B Y-S A}$ licence

All rights reserved.

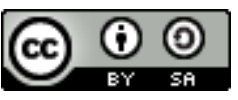

\section{Corresponding Author:}

Endang Nurul Hasanah,

Pendidikan Matematika,

Fakultas Keguruan dan Ilmu Pendidikan,

Universitas Islam Riau,

Jl. Kaharuddin Nst No. 113, Simpang Tiga, Kota Pekanbaru, Riau, 28284, Indonesia

Email: endangnuru1017@student.uir.ac.id

\section{Pendahuluan}

Di Indonesia, pendidikan adalah sarana yang berguna dalam meningkatkan kualitas Sumber Daya Manusia (SDM) dengan cara menguasai Ilmu Pengetahuan dan Teknologi (IPTEK). Pratiwi et al. (2017) menyatakan bahwa pendidikan di Indonesia dituntut untuk dapat menghasilkan seseorang yang akan dijadikan penerus bangsa yang mana berkompeten dalam bidang pengetahuan, sikap serta keterampilan. Di dalam Al-Qur'an surah Mujadilah ayat 11 
juga menjelaskan bahwa Allah SWT yang dimana berjanji menaikkan derajat bagi orang-orang yang beriman diantaranya orang-orang yang berilmu. Pada masa sekarang ini tantangan pada dunia pendidikan yakni seorang pendidik berusaha menciptakan ketertarikan dan semangat belajar pada siswa terlebih lagi pada mata pelajaran yang menurut siswa tergolong sulit yang dimana antara lain yakni matematika.

Matematika adalah pelajaran dimana bisa meningkatkan pola pikir siswa sehingga mereka dapat berfikir dengan bener (logis) serta kritis dimana dihadapkan oleh sebuah permasalahan yang harus diselesaikan (Alvionita et al., 2019). Sebagai mata pelajaran yang dianggap sulit oleh siswa, diperlukan metode pembelajaran yang tepat agar kemampuan hasil belajar siswa dapat maksimal. Metode pembelajaran dalam hal ini sangat berkaitan dengan perangkat pembelajaran. Berdasarkan itu disini guru memilik tugas pokok yakni sebelum melakukan pembelajaran terlebih dahulu guru dapat merancang serta menyusun perencanaan pembelajaran seperti Rencana Pelaksanaan Pembelajaran (RPP), silabus, dan Lembar Kerja Peserta Didik (LKPD) dalam mengembangkannya disesuaikan oleh kurikulum yang digunakan saat ini (Ariawan \& Putri, 2020).

Dari tahap awal yang dilakan yaitu infomasi yang didapat dengan cara melakukan wawancara dengan guru yang mengajar mata pelajaran matematika di SMPN 4 Kunto Darussalam, diperoleh permasalahan pada RPP dan LKPD. Permasalahan pada RPP anatar lain: 1) kegiatan apresepsi materi prasayaratnya tidak jelas yang akan disampaikan; 2) pada point media pembelajaran disebutkan terdapat LKS tetapi di dalam pelaksanaan kegiatan pembelajarannya tidak dimunculkannya LKS tersebut; 3) pada penggunaan waktu tidak terinci dengan jelas dalam pelaksanaan masing-masing kegiatan pembelajarannya; dan 4) pada penggunaan metode tidak tersusun dengan jelas dalam pelaksanaan masing-masing kegiatan pembelajarannya. Adapun kelemahan pada LKPD antara lain: 1) tidak memuat berapa lama waktu yang digunakan dalam pengerjaannya; 2) tidak lengkap strukturnya tidak terdapat Kompetensi Inti (KI), Kompetensi Dasar (KD), Indikator Pencapaian Kompetensi (IPK) dan petunjuk pengerjaannya; 3) tidak memberi ruang untuk hasil kerja eksperimen yang telah dilakukan siswa secara berkelompok; 4) tidak memuat langkah-langkah dari metode yang digunakan; dan 5) tampilannya kurang menarik sehingga siswa menjadi bosan. Dari permasalahan dan kelemahan tersebut, perbaharuan dalam pengembangan dua perangkat pembelajaran ini sangat diperlukan untuk mempermudah tercapainya tujuan pembelajaran.

Adapun alasan mengapa peneliti memilih materi dari bangun ruang sisi lengkung yakni karena menurut Nuraida (2017), Mata pelajaran bangun ruang sisi lengkung dimana terdapat 3 bangun ruang yakni (tabung, kerucut, dan bola) termasuk mata pelajaran bidang geometri begitu sedikit peminatnya lebih tepatnya kurang banyak disukai dan dianggap sulit untuk dipahami oleh peserta didik. Dari informasi wawancara yang didapat dikatakan oleh guru bahwa kelas IX, yang memperoleh nilai rata-rata dari 30 siswa yang mampu mendapatkan hasil diatas KKM pada materi bangun ruang sisi lengkung hanya sebanyak 10 anak. Selain itu, dari hasil penelitian Rachman (2020) menyatakan bahwa faktor permasalahan yang membuat sulit siswa untuk memahami dari mata pelajaran bangun ruang sisi lengkung adalah: 1) anak didik tersebut tidak tertarik dengan mata pelajarannya; 2) peserta didik kesulitan menyebutkan nama dari bagian yang terdapat pada tabung serta yang terdapat pada unsur-unsur pada bola; 3) peserta didik kesulitan dalam mengingat dari rumus-rumus luas permukaan, serta rumus volume tabung, kerucut, serta bola; dan 4) anak didik kesulitan dalam menerapkan rumus dari luas permukaan dan volume dari ketiga bangun ruang tersebut. Dengan demikian peneliti memilih metode penemuan terbimbing karena merasa cocok untuk masalah tersebut karena memudahkan pemahaman konsep.

Hasil penelitian Markaban (2008) menyatakan bahwa adapaun kelebihan metode penemuan terbimbing ini yaitu peserta didik dapat mencapai tingkat kemapuan tinggi dari 
materi yang dipelajari dan lebih meningkatkan daya ingat siswa, karena siswa dilibatkan dalam proses menemukannya sehingga siswa dapat mengingat rumus dari bangun ruang sisi lengkung tersebut lebih lama. Sedangkan pada penelitian Arifin (2014) yang melakukan penggabunagn berupa konsep dari penerapan metode penemuan terbimbing yang berbantu dengan alat peraga, yang dimana diperoleh hasil kalau dari metode ini adanya peningkatan dari hasil belajar yang diperoleh anak didik dan juga aktivitasnya dalam melaksanakan pembelajaran matematika. Dengan pengembangan perangkat pembelajaran metode penemuan terbimbing, proses belajar mengajar menjadi berpusat ke peserta didiknya, dimana ini menyebabkan mereka sangat semangat selama proses belajar mengajar berlangsung. Untuk itu penelitian ini peneliti lakukan dengan judul "Pengembangan Perangkat Pembelajaran Matematika Dengan Metode Penemuan Terbimbing Pada Materi Bangun Ruang Sisi Lengkung Kelas IX SMP Negeri 4 Kunto Darussalam" dengan tujuan untuk menghasilkan berupa RPP dan LKPD dengan metode penemuan terbimbing pada materi bangun ruang sisi lengkung di kelas IX SMP yakni yang teruji kelayakannya (kevalidan).

\section{Metode}

Tempat penelitian yang dilakukan di Universitas Islam Riau Fakultas Keguruan Matematika dan SMP Negeri 4 Kunto Darussalam selama semester ganjil tahun ajaran 2020/2021. Penelitian ini termasuk penelitian pengembangan (Research and Development). Dimana berorientasi pada produk yang dikembangkan yang hasil akhirnya dievaluasi (Angraini

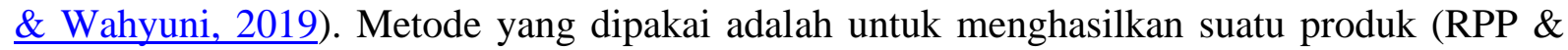
LKPD) tertentu dan tidak lupa untuk menguji efektifitas dari produk yang dihasilkan (Sugiyono, 2013). Produk disini yaitu sekaligus sebagai objek penelitian yakni berupa produk yaitu Rencana Pelaksanaan Pembelajaran (RPP) dan Lembar Kerja Peserta Didik (LKPD) yang menggunakan metode penemuan terbimbing pada mata pelajaran bangun ruang sisi lengkung di kelas IX SMP yang teruji kevalidannya.

Prosedur dalam menggunakan model Research and Development disini peneliti membatasi serta dimodifikasi karena situasi belajar mengajar yang kurang kondusif akibat pandemi Covid-19 dimana proses belajar mengajar masih dilakukan dirumah saja secara daring. Langkah-langkah tersebut meliputi: (1) potensi dan masalah, (2) pengumpulan data, (3) desain produk, (4) validasi desain, (5) revisi desain, dan terakhir (6) produk akhir. Data penelitian dikumpulkan dengan teknik non tes, yakni berupa angket dan diperoleh data hasil uji coba angket validasi. Penilaian dalam analisis data pada lembar validasi menggunakan 2 skala yaitu analisis validitas skala Guttman dan analisis validitas skala Likert.

Hasil dari validasi setiap validator dan hasil analisis validitas gabungan (skala Guttman dan skala Likert) jika telah didapat tingkat persentasinya selanjutnya dapat melihat kriteria validitas yang telah ditetapkan. Penilaian yang dilakukan validator pada lembar validasi tersebut akan menentukan produk yang dikembangkan atau dihasilkan apakah layak untuk diujicoba tidak menggunakan revisi, atau menggunakan revisi, atau bahkan tidak layak diuji cobakan. Selain hasil validasi ini, terdapat juga catatan komentar dan saran atau perbaikan yang diberikan validator sebagai tambahan dapat berupa kelemahan, kelebihan dan kekurangan terhadap produk dikembangkan. 


\section{Hasil Penelitian}

Prosedur dalam penelitian pengembangan berupa perangkat pembelajaran matematika yakni RPP dan LKPD pada materi bangun ruang sisi lengkung pada kelas IX SMP Negeri 4 Kunto Darussalam dengan metode penemuan terbimbing dilakukan berdasarkan langkahlangkah daan hasil yaitu :

1. Potensi dan Masalah

Dari hasil wawancara diperoleh informasi bahwa potensi yang dimiliki guru yaitu kemampuan membuat RPP dengan kurikulum 2013, serta mampu merancang LKPD dengan sendiri. Sedangkan potensi yang dimiliki siswa adalah sudah terbiasa menggunakan LKPD dan mampu menyelesaikan permasalahan yang terdapat pada LKPD tersebut. Sedangkan masalah yang diperoleh yaitu RPP yang digunakan pada kegiatan apresepsi materi prasayaratnya tidak jelas yang akan disampaikan dan belum terdapat penggunaan LKS di dalam pelaksanaan kegiatan pembelajarannya. Sedangkan untuk LKPD itu sendiri tidak lengkap strukturnya dan tidak memberi ruang untuk hasil kerja eksperimen yang telah dilakukan siswa secara berkelompok. Selain itu LKPD yang tersedia tidak memuat langkah-langkah dari metode yang digunakan. Permasalahan lain yang di hadapi yaitu siswa merasa bosan dan jenuh karena LKPD yang tersedia hanya memuat rumus dan soal-soal saja serta tampilan LKPD sendiri tidak menarik, karena didalamnya tidak memuat gambar serta warna yang menarik. Dalam mengatasi masalah tersebut, peran guru yang dimana dalam merancang perangkat pembelajaran sangatlah penting. Guru harus bisa merancang perangkat pembelajaran yang dimana peserta didik lebih semangat dan berperan aktif dalam mengerjakan soal-soal, serta tidak menimbulkan rasa bosan dan jenuh.

2. Pengumpulan Data

Data dan informasi dikumpulkan untuk bahan perencanaan pengembangan perangkat pembelajaran yang dimana bermaksud dapat mengatasi dalam menyelesaikan masalah-masalah yang sedang dihadapi. Adapun cara dalam mengumpulkan data yakni memakai cara dilakukannya analisis kurikulum dan analisis materi. Hasil analisis kurikulum berupa Kompetensi Inti (KI), Kompetensi Dasar (KD) dan juga Indikator Pencapaian Kompetensi (IPK) yang dijadikan beberapa indikator. Selain itu materi pokok bahasan bangun ruang sisi lengkung dapat dipakai sebagai pedoman penyusunan materi. Sedangkan hasil analisis materi berupa uraian dari materi pokok juga akan dijadikan pedoman kertika ingin membuat perangkat pembelajaran. Hasil analisis kurikulum dan analisis materi harus sesuai dengan silabus kurikulum 2013 yang juga digunakan untuk mendukung pengembangan perangkat pembelajaran yang sesuai dengan metode penemuan terbimbing.

Berdasarkan KI dan KD kurikulum 2013 yang digunakan di SMP Negeri 4 Kunto Darussalam, pada materi bangun ruang sisi lengkung siswa diharapkan mampu menguasai pokok bahasan tabung dan kerucut antara lain: 1) Membentuk jaring-jaring tabung dan kerucut melalui eksperimen; 2) Luas permukaan tabung dan kerucut; dan 3) Volume tabung dan kerucut. Untuk mengukur penguasaan pokok bahasan tabung dan kerucut oleh siswa maka dirumuskan indikator pencapaian pembelajaran untuk pokok bahasan materi bangun ruang sisi lengkung tabung dan kerucut yang harus dicapai, adapun indikator tersebut dipaparkan pada Tabel 1 berikut:

Tabel 1. KD dan Indikator Pencapaian Kompetensi

\begin{tabular}{llll}
\hline Kompetensi Dasar & \multicolumn{2}{c}{ Indikator Pencapaian Kompetensi } \\
\hline 3.7 & $\begin{array}{l}\text { Membuat generalisasi luas permukaan } \\
\text { dan volume bangun ruang sisi }\end{array}$ & 3.7 .1 & Peserta didk dapat membuat jaring-jaring tabung \\
\cline { 2 - 3 } & 3.7 .2 & $\begin{array}{l}\text { Peserta didik dapat menemukan dari rumus luas } \\
\text { lengkung (tabung, kerucut dan bola). }\end{array}$ \\
\cline { 2 - 3 } & 3.7 .3 & $\begin{array}{l}\text { Diharaankan anak didik bisa untuk menghitung luas } \\
\text { permukaan dari tabung }\end{array}$ \\
\hline
\end{tabular}




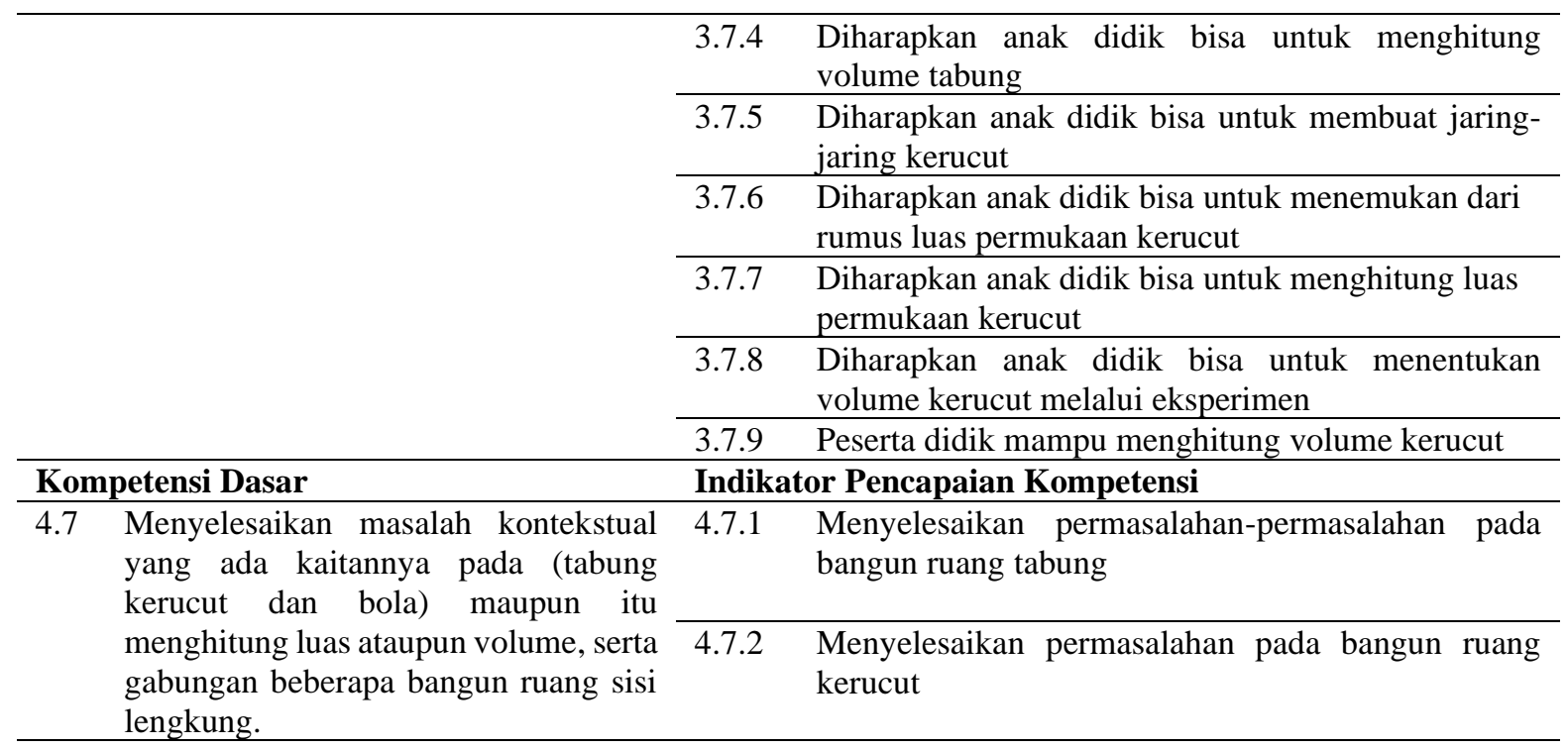

Setelah indikator pencapaian kompetensi dirumuskan, diupayakan agar perangkat pembelajaran yang dikembangkan dapat membantu siswa menyelesaikan permasalahan kontekstual dimana terdapat pada perangkat pembelajaran materi tabung dan kerucut. Peneliti menggunakan metode penemuan terbimbing dalam merancang RPP dan LKPD. Adapaun penggunaan alat peraga dalam materi bangun ruang ini antara lain: kaleng susu yang masih berlebel, uang koin 500 sebanyak 12 buah, dan topi berbentuk kerucut. Selain itu alat dan benda pendukung lain yaitu kertas karton, pasir atau beras, alat tulis, gunting, cutter dan double tip.

3. Desain Produk

Untuk desain produk RPP, disusun berdasarkan kompenen RPP sesuai dengan metode penemuan terbimbing yang ada di dalam kurikulum 2013, yaitu memuat: Satu: Identitas sekolah; Dua: Identitas mata pelajaran; Tiga: Kelas/semester; Empat: Materi pokok; Lima Alokasi waktu; Enam Kompetensi Inti; Tujuh Kompetensi Dasar dan Indikator Pencapaian Kompetensi; Delapan: Tujuan pembelajaran; Sembilan: Materi pembelajaran; Sepuluh: Metode pembelajaran; Sebelas: Media dan sumber belajar; Dua belas Langkah-langkah pembeljaran; dan terakhit Tiga belas: Penilaian hasil belajar. Pengembangan RPP terdiri yang didesain yaitu 4 pertemuan. Awal dari pertemuan pertama, sub pembahasan mengenai membuat jaring-jaring tabung dan mendapatkan rumus dari luas permukaan tabung serta menghitung luas permukaan dari tabung dengan waktu 2 x 40 menit. Tujuan pertemuan pertama pembelajaran ini adalah: 1) Jika sudah mengikuti pembelajaran peserta didik diharapkan bisa membuat jaring-jaring tabung; 2) Setelah mengikut pembelajaran diharapkan anak didik bisa menemukan dari rumus luas permukaan tabung; 3) Setelah mengikut pembelajaran diharapkan anak didik mampu menghitung dari luas permukaan tabung; dan 4) Setelah mengikut pembelajaran diharapkan peserta didik mampu dalam menyelesaikan permasalahan yang terdapat pada tabung.

Pada pertemuan kedua, sub pembahasan mengenai menghitung volume tabung dengan waktu yaitu 2 x 40 menit. Tujuan pada pertemuan kedua ini adalah: 1) Jika sudah mengikut pembelajaran diharapkan siswa dapat menghitung volume tabung; dan 2) Setelah mengikut pembelajaran diharapkan peserta didik mampu menyelesaikan permasalahan yang terdapat tabung. Pada pertemuan ketiga, sub pembahasan mengenai membuat jaring-jaring kerucut, menemukan rumus dari luas permukaan kerucut dan juga menghitung dari luas permukaan kerucut dengan waktu 2 x 40 menit. Tujuan pertemuan ketiga pembelajaran ini adalah: 1) Jika sudah mengikut pembelajaran diharapkan siswa dapat membuat jaring-jaring kerucut; 2) 
Setelah mengikut pembelajaran diharapkan siswa dapat menemukan rumus luas permukaan kerucut; 3) Setelah mengikut proses belajar supaya anak didik bisa menghitung luas permukaan dari kerucut; dan 4) Setelah mengikut proses belajar anak didik mampu dan dapat
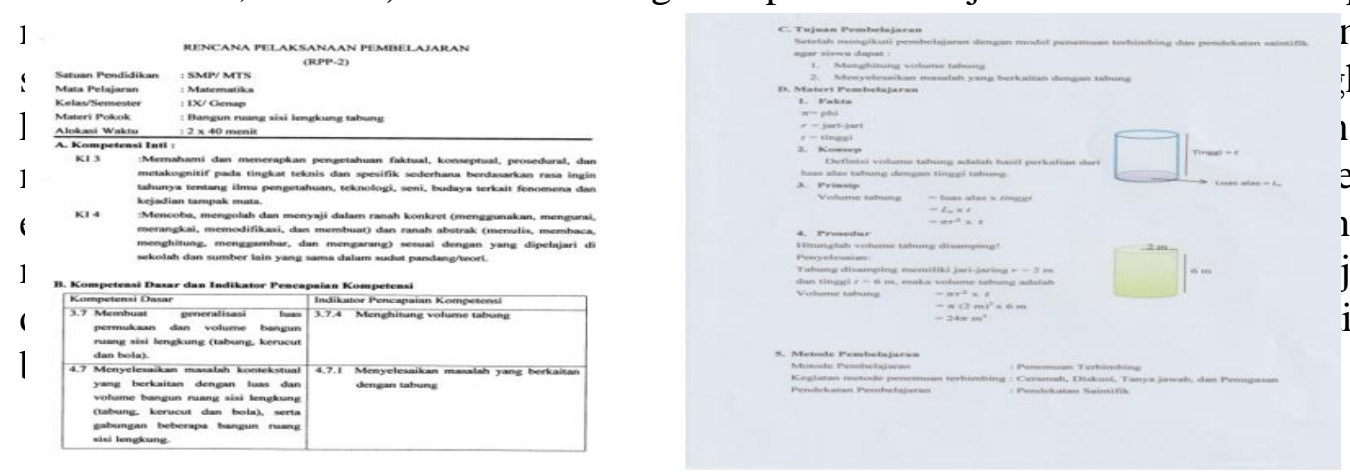
muan keempat, ,hitung volume 1: 1) Jika sudah erucut melalui lak didik bisa jar supaya anak in produk RPP

Gambar 1. Ilustrasi RPP

Selanjutnya pada LKPD, dikembangkan menggunakan metode penemuan terbimbing yang terdiri dari 4 kali pertemuan untuk mata pelajaran bangun ruang sisi lengkung. LKPD ini disusun sesusai dengan RPP yang digunakan dalam proses pembelajaran berlangsung. LKPD yang disusun merupakan panduan dalam siswa mengikuti proses pembelajaran, serta bertujuan untuk mendorong siswa menjadi lebih aktif. LKPD didesain dengan warna dan gambar yang dibuat semenarik mungkin dan juga dilengkapi pula soal dan pembahasan yang disesuaikan dengan materi yang akan dipelajari. Langkah-langkah pengerjaan terdapat di dalam LKPD dibuat terurut serta sesederhana ini bertujuan supaya peserta didik mudah memahami. Berikut ilustrasi desain LKPD yang dikembangkan:

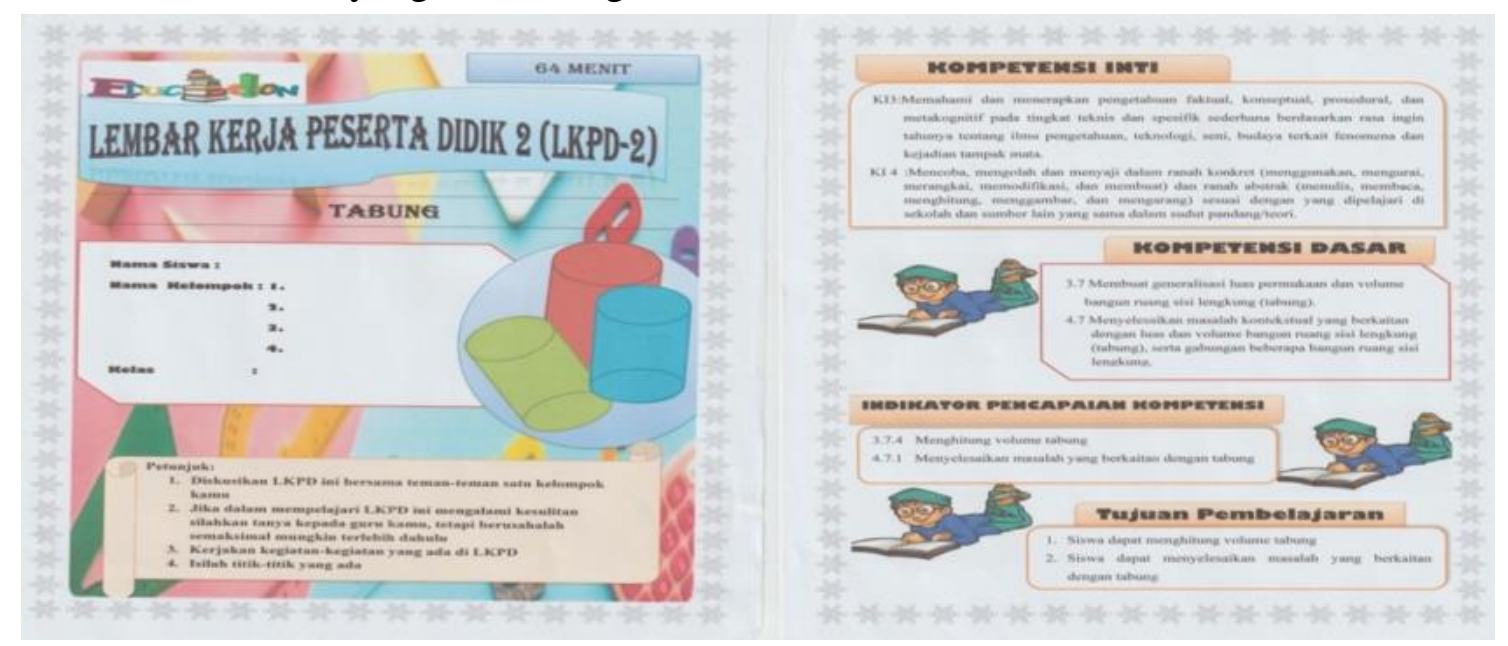

Gambar 2. Ilustrasi LKPD

4. Validasi Desain 
Validasi RPP dilakukan dari senin 7 Juni 2021 sampai Juli 2021 dengan satu kali revisi. Hasil validasi dan revisi RPP dan LKPD dirangkumkan di Tabel 2 dan 3 sebagai berikut:

Tabel 2. Daftar Revisi pada RPP

\begin{tabular}{|c|c|}
\hline Sebelum Revisi & Sesudah Revisi \\
\hline \multicolumn{2}{|r|}{ RPP-1 } \\
\hline $\begin{array}{l}\text { Nama sekolah tertuis : SMP Negeri } 4 \\
\text { Kunto Darussalam }\end{array}$ & Nama sekolah tidak dicantumkan menjadi : SMP/MTS \\
\hline $\begin{array}{l}\text { Penulisan pada IPK kata : mendapatkan } \\
\text { rumus dari luas permukaan tabung }\end{array}$ & $\begin{array}{l}\text { Perubahan kata pada IPK : menemukan rumus dari luas } \\
\text { permukaan tabung }\end{array}$ \\
\hline $\begin{array}{l}\text { Apresepsi tidak tertulis hanya : Guru } \\
\text { memberikan apresepsi dengan cara } \\
\text { mengingatkan siswa mengenai materi } \\
\text { bangun ruang sisi lengkung }\end{array}$ & $\begin{array}{l}\text { Apresepsi tertulis menjadi : Guru memberikan apresepsi dengan } \\
\text { cara mengingatkan siswa mengenai materi persegi panjang dan } \\
\text { lingkaran. "Pada kelas VII dan VIII kalian sudah mempelajari } \\
\text { bangun datar persegi panjang dan lingkaran, disini siapa yang } \\
\text { masih ingat dengan sifat dan rumus luas permukaan dari bangun } \\
\text { datar tersebut?". }\end{array}$ \\
\hline $\begin{array}{l}\text { Motivasi tidak tertulis hanya : Guru } \\
\text { memberikan motivasi kepada peserta } \\
\text { didik }\end{array}$ & $\begin{array}{l}\text { Motivasi tertulis menjadi : Guru memotivasi anak didiknya agar } \\
\text { semangat dalam proses belajar yang akan dilakukan dan tidak lupa } \\
\text { memberi motivasi sesuai mata pelajaran yang dipelajari. "tabung } \\
\text { banyak kita jumpai dalam kehidupan sehari-sehari contohnya } \\
\text { cangkir, kaleng susu dan lain-lain. Dengan memahami sifat-sifat } \\
\text { tabung, kita dapat menyelesaikan permasalahan dikehidupan } \\
\text { sehari-hari yang ada kaitannya pada tabung". }\end{array}$ \\
\hline $\begin{array}{l}\text { Penulisan pada indikator penilaian hasil } \\
\text { belajar yaitu : jenis dan teknik penilian }\end{array}$ & Perubahan kata jenis menjadi : aspek dan teknik penilaian \\
\hline Penilaian sikap tertulis & Penilaian sikap tidak tertulis karena memakai KI-3 dan KI-4 \\
\hline \multicolumn{2}{|r|}{ RPP-2 } \\
\hline $\begin{array}{l}\text { Nama sekolah tertuis : SMP Negeri } 4 \\
\text { Kunto Darussalam }\end{array}$ & Nama sekolah tidak dicantumkan menjadi : SMP/MTS \\
\hline $\begin{array}{l}\text { Apresepsi tidak tertulis hanya : Guru } \\
\text { memberikan apresepsi dengan cara } \\
\text { mengingatkan siswa mengenai materi } \\
\text { bangun ruang sisi lengkung }\end{array}$ & $\begin{array}{l}\text { Apresepsi tertulis menjadi : Guru memberikan apresepsi dengan } \\
\text { cara mengingatkan anak didik dengan materi tabung yang sudah } \\
\text { diajarkan. "kemarin kita sudah mempelajari jaring-jaring dan luas } \\
\text { permukaan tabung. Masih ingatkah kalian dengan rumus mencari } \\
\text { luas permukaan tabung?". }\end{array}$ \\
\hline $\begin{array}{l}\text { Motivasi tidak tertulis hanya : Guru } \\
\text { memberikan motivasi kepada peserta } \\
\text { didik }\end{array}$ & $\begin{array}{l}\text { Motivasi tertulis menjadi : Guru memotivasi anak didiknya agar } \\
\text { semangat dalam proses belajar yang akan dilakukan dan tidak lupa } \\
\text { memberi motivasi sesuai mata pelajaran yang dipelajari. "dengan } \\
\text { memahami rumus volume tabung, kita dapat menyelesaikan } \\
\text { permasalahan dikehidupan sehari-hari yang ada kaitannya pada } \\
\text { tabung dan akan lebih mudah untuk memahami pada materi } \\
\text { pertemuan selanjutnya". }\end{array}$ \\
\hline $\begin{array}{l}\text { Penulisan pada indikator penilaian hasil } \\
\text { belajar yaitu : jenis dan teknik penilian }\end{array}$ & Perubahan kata jenis menjadi : aspek dan teknik penilaian \\
\hline Penilaian sikap tertulis & Penilaian sikap tidak tertulis karena memakai KI-3 dan KI-4 \\
\hline \multicolumn{2}{|r|}{ RPP-3 } \\
\hline $\begin{array}{l}\text { Nama sekolah tertuis : SMP Negeri } 4 \\
\text { Kunto Darussalam }\end{array}$ & Nama sekolah tidak dicantumkan menjadi : SMP/MTS \\
\hline $\begin{array}{l}\text { Apresepsi tidak tertulis hanya : Guru } \\
\text { memberikan apresepsi dengan cara } \\
\text { mengingatkan siswa mengenai materi } \\
\text { bangun ruang sisi lengkung }\end{array}$ & $\begin{array}{l}\text { Apresepsi tertulis menjadi : Guru memberikan apresepsi dengan } \\
\text { cara mengingatkan siswa mengenai materi segitiga dan lingkaran. } \\
\text { "Pada kelas VII dan VIII kalian sudah mempelajari bangun datar } \\
\text { segitiga dan lingkaran, disini siapa yang masih ingat dengan sifat } \\
\text { dan rumus dari bangun datar tersebut?". }\end{array}$ \\
\hline $\begin{array}{l}\text { Motivasi tidak tertulis hanya : Guru } \\
\text { memberikan motivasi kepada peserta } \\
\text { didik }\end{array}$ & $\begin{array}{l}\text { Motivasi tertulis menjadi : Guru memotivasi anak didik agar } \\
\text { semangat dalam proses belajar yang akan dilakukan dan tidak lupa } \\
\text { memberi motivasi sesuai mata pelajaran yang dipelajari. "kerucut }\end{array}$ \\
\hline
\end{tabular}


Sebelum Revisi

Sebelum Revisi $\quad$ Sesudah Revisi

banyak kita jumpai dalam kehidupan sehari-sehari contohnya topi petani ,tutup saji dan lain-lain. Dengan memahami sifat-sifat kerucut, kita dapat menyelesaikan permasalahan dikehidupan sehari-hari yang ada kaitannya pada kerucut".

Pada indikator penilaian hasil belajar Perubahan kata jenis menjadi : aspek dan teknik penilaian

yaitu : jenis dan teknik penilian

Penilaian sikap tertulis

\begin{tabular}{ll}
\hline $\begin{array}{l}\text { Nama sekolah tertuis : SMP Negeri } 4 \\
\text { Kunto Darussalam }\end{array}$ & Nama sekolah tidak dicantumkan menjadi : SMP/MTS \\
\hline $\begin{array}{l}\text { Apresepsi tidak tertulis hanya : Guru } \\
\text { memberikan apresepsi dengan cara } \\
\text { mengingatkan siswa mengenai materi } \\
\text { bangun ruang sisi lengkung }\end{array}$ & $\begin{array}{l}\text { Apresepsi tertulis menjadi : Guru memberikan apresepsi dengan } \\
\text { cara mengingatkan siswa mengenai materi kerucut yang telah } \\
\text { dipelajari. "kemarin kita sudah mempelajari jaring-jaring dan luas }\end{array}$ \\
& $\begin{array}{l}\text { permukaan kerucut. Masih ingatkah kalian dengan rumus mencari } \\
\text { luas permukaan kerucut?" }\end{array}$ \\
\hline $\begin{array}{l}\text { Motivasi tidak tertulis hanya : Guru } \\
\text { memotivasi anak didik }\end{array}$ & $\begin{array}{l}\text { Motivasi tertulis menjadi : Guru memotivasi anak didik agar } \\
\text { semangat dalam proses belajar yang akan dilakukan dan tidak lupa }\end{array}$ \\
& $\begin{array}{l}\text { memberi motivasi sesuai mata pelajaran yang dipelajari. "dengan } \\
\text { memahami rumus volume kerucut, kita bisat menyelesaikan }\end{array}$ \\
& $\begin{array}{l}\text { permasalahan dikehidupan sehari-hari yang berkaitan pada } \\
\text { kerucut dan akan lebih mudah untuk memahami pada materi } \\
\text { pertemuan selanjutnya". }\end{array}$
\end{tabular}

Penulisan pada indikator penilaian hasil belajar yaitu : jenis dan teknik penilian Perubahan kata jenis menjadi : aspek dan teknik penilaian Penilaian sikap tertulis

\begin{tabular}{c}
\hline Penilaian sikap tertulis \\
\hline Sebelum Revisi \\
\hline Tabel 3. Da \\
\hline Langkah 1. Merumuskan Masalan \\
\hline $\begin{array}{c}\text { Tahukah kamu bentuk dari bangun ruang tabung? } \\
\text { Tahukakh kamu bagaimana cara untuk } \\
\text { mendapatkan jaring-jaring tabung? }\end{array}$ \\
\hline
\end{tabular}

Tidak tertulis informasi tentang jaring-jaring, dan perbaiki kata-kata agar tidak membingungkan siswa
Penilaian sikap tidak tertulis karena memakai KI-3 dan KI-4 


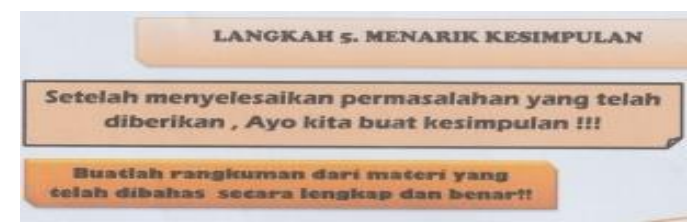

Penimbulan penafsiran ganda anatara rangkuman dan kesimpulan pada langkah ke -5

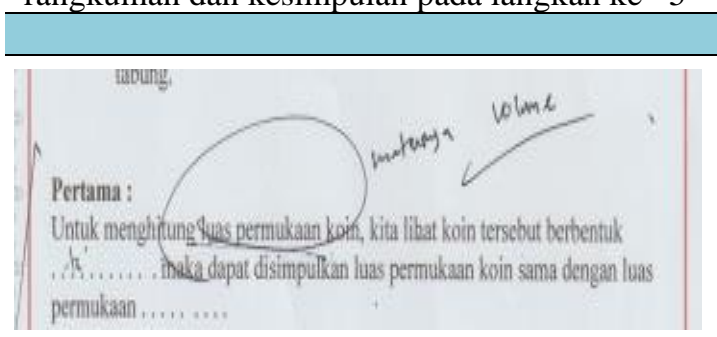

Penggunaan kata tidak tepat yang akan membuat siswa bingung : Untuk menghitung luas permukaan koin, kita lihat koin berbentuk..

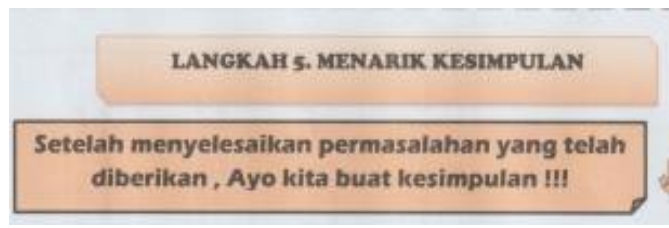

Penghilangan kata rangkuman pada langkah- 5

\section{LKPD-2}

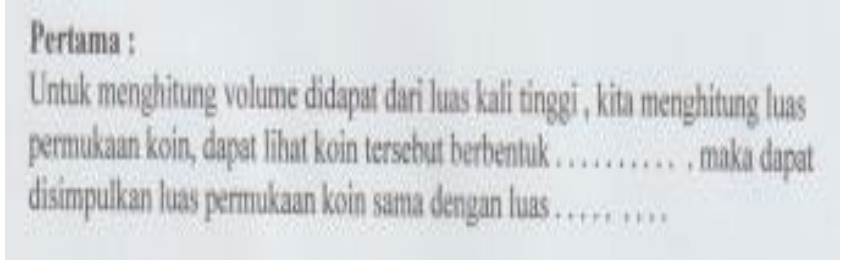

Perbaikan kata yang tepat: Untuk menghitung volume didapat dari luas kali tinggi, kita menghitung luas permukaaan koin, dapat lihat koin tersebut berbentuk......

\section{Hasil Penilaian Produk}

Setelah produk selesai direvisi, peneliti melakukan validasi kepada validator. Adapun kategori penilaian pada lembar validasi RPP yaitu menggunakan 2 skala yakni skala likert dengan penilaian (4) sangat sesuai/sangat jelas, (3) sesuai/jelas, (2) kurang sesuai/kurang jelas, dan (1) tidak sesuai/tidak jelas. Berikutnya skala guttman dengan penilaian (1) ya dan (0) tidak. Penilaian validator terhadap RPP terdiri dari indikator yaitu: kelengkapan komponen RPP, kesesuaian antar komponen/ isi RPP, kejelasan rumusan kegiatan pembelajaran dengan metode penemuan terbimbing, kesesuaian bahasa, kesesuaian waktu. Hasil penilaian akhir yang dilakukan validator pada pengembangan RPP yang peniliti buat setelah melakukan revisi hasilnya di tabel 4 di bawah ini:

Tabel 4. Hasil Validasi RPP

\begin{tabular}{cccccc}
\hline \multirow{2}{*}{ RPP } & \multicolumn{3}{c}{ Persentase Validasi (\%) } & \multirow{2}{*}{ Rata-Rata (\%) } & \multirow{2}{*}{ Kategori } \\
\cline { 2 - 4 } & Validator 1 & Validator 2 & Validator 3 & & \\
\hline RPP-1 & $97,91 \%$ & $86,45 \%$ & $81,25 \%$ & $88,53 \%$ & Sangat Valid \\
RPP-2 & $97,91 \%$ & $86,45 \%$ & $81,25 \%$ & $88,53 \%$ & Sangat Valid \\
RPP-3 & $97,91 \%$ & $86,45 \%$ & $81,25 \%$ & $88,53 \%$ & Sangat Valid \\
RPP-4 & $97,91 \%$ & $86,45 \%$ & $81,25 \%$ & $88,53 \%$ & Sangat Valid \\
\hline \multicolumn{7}{c}{ Rata-Rata Total } & $88,53 \%$ & Sangat Valid \\
\hline
\end{tabular}

Berdasarkan dari penilaian ketiga validator maka RPP dari pertemuan pertama sampai pertemuan keempat memiliki validitas Sangat Valid mempunyai rata-rata yaitu $88,53 \%$ 
sehingga dari hasil tersebut ditetapkan bahwa RPP yang dikembangkan dengan metode penemuan terbimbing ini layak digunakan dan revisi sesuai dengan saran. Setelah produk LKPD selesai direvisi, peneliti melakukan validasi kepada validator. Adapun kategori penilaian yang ada dilembar validasi LKPD yaitu menggunakan 2 skala yakni skala likert dalam kategori penilaiannya yaitu (4) sangat menarik, (3) menarik, (2) kurang menarik, dan (1) tidak menarik. Berikutnya skala guttman dengan penilaian (1) ya dan (0) tidak. Penilaian validator terhadap LKPD meliputi beberapa indikator, yaitu: kelengkapan komponen LKPD, indikator isi, indikator bahasa, indikator penyajian, indikator waktu. Hasil penilaian akhir yang dilakukan validator pada pengembangan LKPD peniliti buat setelah melakukan revisi hasilnya di tabel 5 di bawah ini:

Tabel 5. Hasil Validasi LKPD

\begin{tabular}{cccccc}
\hline \multirow{2}{*}{ RPP } & \multicolumn{3}{c}{ Persentase Validasi (\%) } & \multirow{2}{*}{ Rata-Rata (\%) } & \multirow{2}{*}{ Kategori } \\
\cline { 2 - 4 } & Validator 1 & Validator 2 & Validator 3 & & Sangat Valid \\
LKPD-1 & $98,65 \%$ & $86,24 \%$ & $81,25 \%$ & $88,71 \%$ & Sangat Valid \\
LKPD-2 & $98,65 \%$ & $86,24 \%$ & $81,25 \%$ & $88,71 \%$ & Sangat Valid \\
LKPD-3 & $98,65 \%$ & $86,24 \%$ & $81,25 \%$ & $88,71 \%$ & Sangat Valid \\
LKPD-4 & $98,65 \%$ & $86,24 \%$ & $81,25 \%$ & $88,71 \%$ & Sangat Valid \\
\hline \multicolumn{7}{c}{} \\
\hline
\end{tabular}

Berdasarkan dari penilaian ketiga validator maka LKPD dari pertemuan pertama sampai pertemuan keempat memiliki validitas Sangat Valid yang dimana memiliki rata-rata sebesar $88,71 \%$ sehingga dari hasil tersebut ditetapkan bahwa LKPD yang telah dikembangkan dengan metode penemuan terbimbing ini layak digunakan dan revisi sesuai dengan saran.

\section{Produk Akhir}

Produk akhir dari penelitian yaitu berupa perangkat pembelajaran yakni Rencana Pelaksanaan Pembelajaran (RPP) dan Lembar Kerja Peserta Didik (LKPD) dengan menggunakan metode penemuan terbimbing pada materi bangun ruang sisi lengkung kelas IX SMP yang telah direvisi berdasarkan saran dan masukan dari para validator.

\section{Diskusi}

Tingkat validitas sangat valid pada hasil validitas pengembangan perangkat pembelajaran berupa RPP pada penelitian ini, dikarenakan RPP yang dikembangkan oleh peneliti setelah dianalisis telah sesuai dengan spesifikasi produk dan kriteria dari kevalidan RPP yang telah ditentukan sesuai teori. Peneliti membuat RPP dengan memodifikasi komponen RPP yang dikemukakan oleh permendikbud Nomor 65 Tahun 2013, yaitu: (1) identitas sekolah; (2) kelas/semester; (3) materi pokok; (4) alokasi waktu; (5) kompetensi inti, kompetensi dasar dan indikator pencapaian kompetensi; (6) tujuan pembelajaran; (7) materi pembelajaran; (8) pendekatan dan model pembelajaran; (9) media, alat, dan sumber belajar; (10) langkah-langkah pembelajaran (pendahuluan, inti, dan penutup); (11) penilaian hasil belajar. Selain itu, RPP yang dirancang telah memuat tujuan pembelajaran, materi ajar, metode pengajaran, sumber belajar, dan penilaian hasil belajar sebagaimana yang telah diatur dalam Pemerintah (PP) nomor 19 tahun 2005 tentang Standar Nasional Pendidikan Pasal 20. RPP dalam penelitian ini juga berisi unsur-unsur sebagaimana yang disebutkan oleh Daryanto \& Aris (2014) yang menyatakan bahwa kejelasan Kompetensi Dasar (KD) yang akan dimilik siswa, dan juga yang akan dipelajari, lalu yang akan dilakukannya, serta bagaimana cara mempelajarinya, dan 
bagaimana seorang guru dapat mengetahui siswanya mengusai kompetensi tertentu yang dimana unsur-unsur tersebut harus terdapat pada RPP.

RPP dibuat dan disusun secara sistematis serta beraturan guna dalam memudahkan pencapaian tujuan yang akan diinginkan. Sejalan dengan kesimpulan penelitian Anggriani \& Indihadi (2018) yang menyebutkan bahwa RPP merupakan perangkat pembelajaran yang dibuat guru dengan sadar dan juga terarah yang direncanakan untuk kegiatan pembelajaran di dalam lokal dengan harapan tujuan dari pembelajaran tersebut akan tercapai. Peneliti memperoleh dengan tingkat validitas sangat valid yang dimana memiliki rata-rata sebesar sebesar 88,53\% maka dari hasil yang diperoleh dapat dinyatakan bahwa RPP yang dikembangkan dengan metode penemuan terbimibing ini layak diuji cobakan dengan revisi sesuai saran dan arahan.

Selain RPP, produk pengembangan lainnya yang dihasilkan yaitu LKPD . Adapun tingkat validitas sangat valid pada hasil validitas pengembangan produk berupa LKPD pada penelitian ini dikarenakan LKPD yang dikembangkan oleh peniliti setelah di analisis telah sesuai dengan spesifikasi produk dan kriteria dari kevalidan LKPD yang telah ditentukan pada kajian teori pada bab 2 dalam penelitian ini. Peneliti memperoleh dengan tingkat validitas sangat valid yang dimana memiliki rata-rata sebesar $88,71 \%$ maka dari hasil yang diperoleh dapat dinyatakan bahwa LKPD yang dikembangkan dengan metode penemuan terbimibing ini layak diuji cobakan dengan revisi sesuai saran dan arahan.

Untuk validasi pengembangan perangkat pembelajaran berupa RPP maupun LKPD ini, keduanya sama-sama dilakukan oleh 3 validator agar diperoleh hasil validitas yang akurat. Hal ini sejalan dengan penelitian Cahyono (2017) dimana penilaian dari produk yang dikembangkan (RPP dan LKPD) ini yang melakukkannya sebanyak 3 orang validator untuk diperiksa dan diberi skor yang berkaitan dengan kevalidan produk pengembangan. 3 validator dalam penelitian ini merupakan validator ahli dengan profesi sebagai dosen dan guru matematika. Khoiriyah et al., (2014) menyatakan bahwa kriteria dari kevalidan yaitu didapat dari para ahli yang sudah melakukan analisis terhadap validasi. Adapun menurut Sumarno \& Wustqa (2014), setelah data sudah diperoleh dari para ahli/praktisi selanjutnya dianalisis dimana bertujuan untuk mengetahui kevalidan dariproduk yang dikembangkan yang ditinjau secara teoritis dan juga konsistensi diantara komponen-komponen dari perangkat pembelajaran. Penilaian validasi pada penelitian ini juga dari beberapa aspek. Sebagaimana yang disebutkan oleh Revita (2017) bahwa aspek yang dinilai pada validasi RPP adalah komponen RPP dan kegiatan pembelajaran, sedangkan pada validasi LKPD adalah aspek didaktik, isi, bahasa, penyajian, dan waktu. Yuniarti et al. (2014) berpendapat bahwa perangkat pembelajaran akan yang valid yang dimana perangkat itu berdasarkan pada raisonal teoritik yang kuat dan memuat konsistensi internal.

Dari keseluruhan hasil, RPP dan LKPD dapat dipergunakan dalam pelajaran matematika dan dapat mempermudah pemahaman siswa terkait materi dari bangun ruang sisi lengkung. Yani (2019) menyatakan bahwa dalam memahami tentang suatu konsep matematika itu hal yang penting oleh setiap siswa agar dapat menggunakan konsep yang telah dipahaminya dalam menyelesaikan permasalahan matematika. LKPD pada penelitian ini berisi langkahlangkah atau petunjuk yang diberikan untuk anak didik supaya tidak kesulitan memahami mata pelajaran yang dipelajari. Sebagaimana dipaparkan oleh Riskawati et al. (2018) bahwa LKPD berupa Lembar Kerja Siswa (LKS) adalah alat untuk belajar yang dicetak dimana memuat lembaran-lembaran kertas yang memuat materi pelajaran, rangkuman,serta petunjuk dalam melakukan tugas, dimana mengacu pada kompetensi yang akan dicapai. Sejalan dengan Pawestri \& Sukoco (2017), yang menyebutkan LKS adalah beruapa lembaran-lembaran 
memuat kegiatan dan pentunjuk dalam melakukan pembelajaran. Adapun menurut Norsanty \& Chairani (2016), bahwa LKS berfungsi yaitu ditunjukkan agar dapat lebih membimbing peserta didik untuk menemukan dan memahami konsep dari mata pelajaran yang dipelajarinya..

Pengembangan produk berupa RPP dan LKPD pada penelitian yang dimana menggunakan metode penemuan terbimbing ini, agar bisa membantu pendidik (guru) melakukan proses pembelajaran mata pelajaran bangun ruang sisi lengkung sekaligus memudahkan mencapai tujuan dari pelajaran tersebut sesuai yang telah diinginkan. Sebagaimana yang disebutkan oleh Igidius (2015), menyatakan dimana perangkat pembelajaran yaitu kelengkapan dari proses belajar mengajar yang dimana dibuat oleh pengajar (guru) sebagai salah satu bentuk persiapan sebelum melaksanakan proses belajar dengan maksud tercapai tujuan yang telah diinginkan. Sedangkan sebagaimana yang dipaparkan oleh Rahmawati et al., (2014) dalam penelitiannya yang menyimpulkan bahwa penemuan terbimbing didasari pembelajaran inkuiri dimana bertujuan ditingkatkannya pemahaman siswa serta motivasi siswa dalam belajar mata pelajaran matematika.

\section{Simpulan}

Pengembangan perangkat pembelajaran matematika dengan metode penemuan terbimbing pada materi bangun ruang sisi lengkung kelas IX SMP yakni berupa Rencana Pelaksanaan Pembelajaran (RPP) dan Lembar Kerja Peserta Didik (LKPD) yang teruji kevalidannya dengan hasil data yang didapatkan yakni sangat valid dengan persentase untuk RPP sebesar $88,53 \%$ dan LKPD sebesar $88,71 \%$. Adapun penelitian ini terbatas yakni hanya menghasilkan RPP dan LKPD yang menggunakan metode penemuan terbimbing, maka direkomendasikan untuk peneliti selanjutnya agar mengembangkan produk lebih lanjut dengan model atau metode yang berbeda dan disarankan untuk menguji cobakan di lapangan agar dapat mengetahui hasil kepraktisan dari perangkat pembelajaran yang dikembangkan tersebut.

\section{Konflik Kepentingan}

Penulis menyatakan tidak ada konflik kepentingan

\section{Referensi}

Alvionita, E., Abdurrahman, \& Herlina, S. (2019). Pengembangan Perangkat Pembelajaran Matematika dengan Model Guided Discovery Learning Pada Materi Barisan dan Deret. Aksiomatik, 7(1), 48-55.

Anggriani, W., \& Indihadi, D. (2018). Analisis Rencana Pelakasanaan Pembelajaran dalam Pembelajaran Menulis Narasi di SD. Jurnal Ilmiah Pendidikan Guru Sekolah Dasar, 5(1), 11-22.

Angraini, L. M., \& Wahyuni, A. (2019). Pengembangan Bahan Ajar Berbasis Pemecahan Masalah Pada Mata Kuliah Aljabar Linear. Euclid, 8(1), 72-82.

Ariawan, R., \& Putri, K. J. (2020). Pengembangan Perangkat Pembelajaran Matematika Dengan Menggunakan Pendekatan Saintifik Berbasis Problem Based Learning. Juring (Journal for Research in Mathematics Learning), 3(3), 293-302. 
Arifin, R. (2014). Penerapan Metode Penemuan Terbimbing berbantu Alat Peraga Matematika untuk Meningkatkan Aktivitas dan Hasil Belajar Siswa Kelas V SD Negeri 20 Kota Bengkulu. Universitas Bengkulu.

Cahyono. (2017). Pengembangan Perangkat Pembelajaran Problem Based Learning Berorientasi Pada Kemampuan Berpikir Kreatif dan Inisiatif Siswa. Phytagoras: Jurnal Pendidikan Matematika, 12(1), 1-11.

Daryanto, \& Aris, D. (2014). Pengembangan Perangkat Pembelajaran. Yogyakarta: Gava Media

Igidius. (2015). Pengembangan Perangkat Pembelajaran Model Kooperatif Tipe Jigsa W Berbasis Kurikulum 2013. Jurnal Pendidikan Vokasi, 3(2), 117-126.

Khoiriyah, J., Suharto, S., \& Trapsilasiwi, D. (2014). Pengembangan Rencana Pelaksanaan Pembelajaran dan Lembar Kerja Siswa Model Pembelajaran CORE dengan Teknik Mind Mapping Pokok Bahasan Bangun Ruang Sisi Lengkung Kelas IX SMP. KADIKMA, 5(3), 137-146.

Markaban. (2008). Model Penemuan Terbimbing Pada Pembelajaran Matematika SMK. Yogyakarta: Pusat Pengembangan Dan Pemberdayaan Pendidik Dan Tenaga Kependidikan Matematika.

Norsanty, U. O., \& Chairani, Z. (2016). Pengembangan Lembar Kerja Siswa (LKS) Materi Lingkaran Berbasis Pembelajaran Guided Discovery Untuk Siswa SMP Kelas VIII. Jurnal Pendidikan Matematika, 2(1), 12-23.

Nuraida, I. (2017). Analisis Kesalahan Penyelesaian Soal Bangun Ruang Sisi Lengkung Siswa Kelas IX SMP Negeri 5 Kota Tasikmalaya. Jurnal Teori Dan Riset Matematika (Teorema), 1(2), 25-30.

Pawestri, E., \& Sukoco, H. (2017). Pengembangan Perangkat Pembelajaran Lembar Kerja Siswa Dengan Pendekatan Kontekstual Untuk Meningkatkan Kemampuan Pemecahan Masalah Siswa. Jurnal Mercumatika: Jurnal Penelitian Matematika Dan Pendidikan Matematika, 2(1), 69-76.

Pratiwi, I., Yulianti, D., \& Dwijananti, P. (2017). Membangun Karakter Siswa Melalui Model Pembelajaran Problem Based Instruction Berbantuan LKS Berpendekatan Scientific. UPEJ Unnes Physics Education Journal, 6(2), 64-73.

Rachman. (2020). Pengembangan Mobile Learning Barusikung Berbasis Android pada Materi Bangun Ruang Sisi Lengkung. Jurnal Pendidikan Matematika, 9(3), 475-486.

Rahmawati, Y., Mardiyana, M., \& Subanti, S. (2014). Pengembangan Perangkat Pembelajaran Berbasis Penemuan Terbimbing (Guided Discovery) dengan Pendekatan Somatic, Auditory, Visual, Intellectual (SAVI). Jurnal Elektronik Pembelajaran Matematika, 2(4), $379-388$. 
Revita, R. (2017). Validitas Perangkat Pembelajaran Matematika Berbasis Penemuan Terbimbing. Suska Journal of Mathematics Education, 3(1), 15-26.

Riskawati, D., Buyung, B., \& Yarmayani, A. (2018). Pengembangan Lembar Kerja Siswa (Lks) Berbasis Penemuan Terbimbing Pada Materi Bangun Ruang Sisi Lengkung. Jurnal Pendidikan Matematika, 2(1), 1-6.

Sugiyono. (2013). Metode Penelitian Administrasi Dilengkapi Dengan Metode R\&D. Bandung: Alfabeta.

Sumarno, S., \& Wustqa, D. U. (2014). Pengembangan Perangkat Pembelajaran Pada Materi Pokok Kalkulus SMA Kelas XI Semester 2. Jurnal Riset Pendidikan Matematika, $1(2), 258-268$.

Yani. (2019). Analisis Kemampuan Pemahaman Matematika Siswa Pada Materi Bangun Ruang Sisi Lengkung. Jurnal Pendidikan Matematika, 8(2), 203-214.

Yuniarti, T., Riyadi, R., \& Subanti, S. (2014). Pengembangan Perangkat Pembelajaran Berbasis Masalah (Problem Based Learning) Dengan Pendekatan Ilmiah (Scientific Approach) Pada Materi Segitiga. Jurnal Elektronik Pembelajaran Matematika, 2(9), 911-921. 